\title{
Protected Area Governance and Its Influence on Local Perceptions, Attitudes and Collaboration
}

\author{
Jesse Sey Ayivor ${ }^{1, *}$, Johnie Kodjo Nyametso ${ }^{2}$ and Sandra Ayivor ${ }^{3}$ (i) \\ 1 Institute for Environment and Sanitation Studies, University of Ghana, Legon, Accra, Ghana \\ 2 Department of Environment and Development Studies, Central University, Accra, Ghana; \\ jnyametso@central.edu.gh \\ 3 College of Education and Human Services, West Virginia University, Morgantown, WV 26505, USA; \\ sa00018@mix.wvu.edu \\ * Correspondence: jsayivor@staff.ug.edu.gh; Tel.: +233-244213287
}

Received: 23 June 2020; Accepted: 30 August 2020; Published: 2 September 2020

\begin{abstract}
Globally, protected areas are faced with a myriad of threats emanating principally from anthropogenic drivers, which underpins the importance of the human element in protected area management. Delving into the "exclusive" and "inclusive" approaches to nature conservation discourse, this study explored the extent to which local communities collaborate in the management of protected areas and how the governance regime of these areas influences local perceptions and attitudes. Data for the study were collected through stakeholder interviews, focus group discussions as well as a probe into participating groups' collective perceptions and opinions on certain key issues. A total of 51 focus group discussions were held in 45 communities involving 630 participants. The analysis was done using qualitative methods and simple case counts to explain levels of acceptance or dislike of issues. The results showed that the objectives of state-managed protected areas, by their nature, tend to exclude humans and negatively influence local perceptions and attitudes. This, in addition to human-wildlife conflicts and high handedness by officials on protected area offenders, affects community collaboration. The study concluded that for protected area management to be effective, effort must be made to positively influence local perceptions and attitudes by promoting "win-win-win" partnerships among all stakeholders.
\end{abstract}

Keywords: local collaboration; governance regime; local attitudes; local perceptions; protected area

\section{Introduction}

Protected areas (PAs) have remained the bedrock of nature conservation, and by far, the best strategy to protect habitats and stem the rapid erosion of biodiversity [1,2]. The Convention on Biological Diversity defines a protected area (PA) as a: "geographically defined area, which is designated or regulated and managed to achieve specific conservation objectives" [3]. The International Union for Conservation of Nature (IUCN), however, provides a universally accepted definition of a protected as "a clearly defined geographical space recognized, dedicated and managed, through legal or other effective means, to achieve the long-term conservation of nature and its associated ecosystems services and cultural values" [3]. The historical antecedent of the establishment of PAs stemmed from the belief in the restorative powers of 'a little pure wilderness,' rooted in the romantic-transcendental preservation ethic [4]. This was a deterministic worldview with a cause and effect relationship, in which the proponents believed that experiencing original nature provided aesthetic, psychological and spiritual benefits that could not be gained in urban or even pastoral landscapes [5]. This line of thought prompted the establishment of large national parks and reserves where natural ecosystems could be protected from human influence, and biodiversity could be conserved [6]. 
Contrary to this worldview, also referred to as the "exclusive model," is the widely acclaimed 'socially oriented paradigm' of PA management [7], which blends conservation objectives with concerns for the wellbeing of local communities [8-14]. The proponents of this approach, referred to as the "inclusive model," are of the view that local people would most likely be willing to conserve when they receive direct benefits from the conservation enterprise. This approach promotes local community collaboration in the decision-making process and enhances dialogue, transparency, mutual respect, equity and benefit-sharing.

Another important conservation approach based on multi-stakeholder engagement is matrix-based conservation [15]. This approach stresses the importance of maintaining suitable habitats and populations of native species outside PAs. According to Lindenmayer and Franklin, [15], it involves the regulatory control of landscape activities such as farming and logging, as well as hunting, to protect species not only within the PA but the entire landscape. This landscape-level approach, however, presents a challenge in sub-Saharan Africa, where land ownership and livelihood issues make its implementation difficult.

In general, socio-economic and cultural factors, to a large extent, influence conservation decisions in most developing countries [16]. Poverty is a major socio-economic characteristic of most communities bordering PAs in these countries. This raises challenges because local communities who, hitherto, derive their livelihood from forest resources and other ecosystem services before PA establishment, tend to be denied access after their establishment [8,17]. Lea et al. [18] explained that the strict protectionists' approach tends to displace people and deprive them of their livelihoods, thereby exacerbating their poverty situation. On the cultural front, the traditional land tenure system is a major factor influencing conservation decisions by local communities in most developing countries. According to the International Fund for Agricultural Development (IFAD), [19], land tenure issues are of prime concern presently, as high rate of population growth, high food prices, the impact of climate change, trade regimes and growing demand for agrofuels, among other factors, have continued to exert pressure on land tenure systems. Moreover, land for wildlife conservation may belong to private individuals, community groups or the state. However, since wildlife is a fugitive property that does not recognize property boundaries, its movement cannot be restricted, hence incessant human-wildlife conflicts [19] occur in the absence of matrix-based conservation.

As noted by Parker et al. [7], the primary focus of PA management has been related to the benefits these areas provide at a higher level, including the protection of biodiversity, spiritual benefits and economic gains through tourism, with less attention given to possible concerns raised by local communities on how they have been disadvantaged by PA establishment. In Africa, most PAs are under state-managed governance regime with little or no provision for local community collaboration. This raises the question as to how practicable local collaboration is in PA management if the governance regime does not realistically involve local people. This study, therefore, examined how PA governance regime influences multi-stakeholder collaboration in PA management in Ghana. More specifically, the study investigated the general threats faced by PAs in selected sites, how the prevailing governance regime has influenced local community perceptions and attitudes, as well as conservation outcomes by way of threat reduction.

\section{Theoretical Underpinnings}

A protected area governance regime is critical in understanding the degree to which local people collaborate in protected area management. In general terms, management refers to "the process of assembling and using sets of resources in a goal-directed manner to accomplish tasks in an organization" [20] p. 4. With regard to protected areas, it involves planning, directing, organizing and evaluating [21]. Governance, on the other hand, relates to power, relationships, responsibility and accountability. In a protected area context, it refers to "who holds management authority and responsibility and can be held accountable according to legal, customary or otherwise legitimate rights" [22] p. 19. Governance also covers broad issues ranging from policy to practice, 
from behavioral issues to meaning, and from investments to impacts in relation to protected areas [22]. Borrini-Feyerabend et al. [23] proposed a fundamental distinction between governance regimes and categorized them into four types, namely: government-managed (solely managed by government agencies); co-managed (management responsibility and authority shared among several actors); privately managed (exclusively in private hands); and community-managed (where management is conducted by local people). Based on these governance types, West and Brechin [24] came out with the dual model-the "exclusive" and "inclusive" approaches—to explain different governance regimes.

In general, a state-managed PA governance regime by its design excludes local people. Thus, to promote inclusiveness and benefit-sharing with neighbouring communities, IUCN introduced a set of universal PA definitions based on six management categories. These are Category IA (strict nature reserve), Category IB (wilderness area), Category II (national park), Category III (natural monument), Category IV (habitat/species management area), Category V (protected landscape/seascape) and Category VI (protected area with sustainable use of natural resources) [3]. The purpose was for each member country to have a blend of several categories of PAs so that while some may allow for a certain level of human activities, others would remain exclusive in order for the PA system to meet both scientific and socio-economic needs.

The numerous challenges which characterize the exclusive approach $[18,25-28]$ led to a paradigm shift, with the inclusive approach now taking center stage. The World Wildlife Fund (WWF), Reference [29] defined collaboration as a mutually beneficial relationship between two or more parties who work toward common goals by sharing responsibility, authority, and accountability for achieving results. This view sees the interests of local people as central to the area being protected and seeks to promote community collaboration in management and planning. Mulongoy and Chape [30] outlined three basic processes for a collaborative approach. These involve dialogue among the various stakeholders and a focus on ecologically sensitive livelihoods, equitable distribution of costs and benefits and the creation of institutions such as joint management boards or village conservation committees. The strengths of the collaborative approach lie in the fact that it is humane, transparent and based on democratic principles, hence its wide acceptability [31]. The approach is also important because it brings groups with similar or different perspectives together to exchange viewpoints and search for solutions that go beyond their own vision of what is possible. It, thus, responds to complex problems and challenges that isolated efforts cannot solve [29].

To enhance effective collaboration, Kemmis [32], in line with others [33-35], suggested that round table discussions in a democratic manner can help to identify more diverse and higher-level public goods than what each person, on their own, can bring to the table. Meffe et al. [34] designed an ecosystem management framework with three contextual elements, namely, ecological, socio-economic and institutional contexts [34]. The framework prescribed "win-win-win" solutions, which they explained as being community-based ecosystem management that provides an organizing framework blending the three contextual elements. This converging point essentially promotes a governance regime in which all stakeholder-interests are achieved without anyone unduly disadvantaged. They identified four zones of ecosystems management, as represented in Figure 1, namely: 


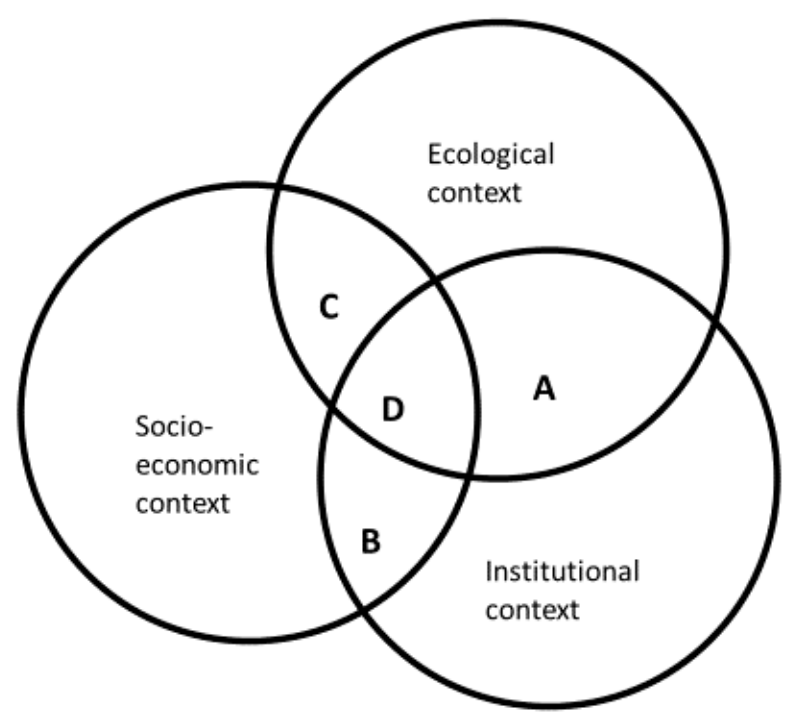

Figure 1. Zones of Ecosystems Management. Source: Modified from Meffe, [34].

A-the zone of regulatory or management authority where enforcement and regulation dictate decision-making as pertains in all PAs;

B-the zone of societal obligations, which does not directly influence natural resource management but indirectly impacts decisions. Examples may include policies that integrate local needs in management systems to ensure equity and fairness;

C-the zone of influence where interpersonal relationships and informal processes prevail, for example, man-nature interaction where activities inimical to the environment prevail;

D-the zone of win-win-win partnerships in which multi-stakeholder collaboration prevails and where there is fairness and equity among all partners.

The zone of "win-win-win" partnerships, according to Meffe et al. [34], is the ideal zone to operate to ensure that institutions regulate and dictate decisions within the ecological context, while at the same time satisfying socio-economic needs of local people. These multifaceted dimensions in ecosystems management and PA governance were later buttressed by Feurt [36] in the concept of collaborative knowledge networks, which captures the relationships among PA managers, local communities and organizations with shared missions for sustaining natural systems in locally valued places.

Several commentators have, however, expressed reservations about the effectiveness of a collaborative approach. Borrini-Feyerabend et al. [23], for instance, argued that PA governance is much more complex than the model intends to explain because, in real terms, a continuum of options exists for sharing authority between the governmental agency in charge and the concerned communities. These authors explained that along the continuum, PA officials may ignore the interests and capacities of local stakeholders and repress all unlawful relationships with the PA. Chicchon [37] also doubted the effectiveness of a collaborative approach and argued that whereas PA managers' interests are driven by the political viability of PAs with biodiversity conservation as the primary goal, local people's interests are not necessarily conservation-driven but rather driven by economics. Cooke and Kothari [38] have argued that local communities, often targeted for collaboration, are rarely politically cohesive and have no collective voice. Terborgh and van Schaik [39] opined that a collaborative model is not likely to succeed where the local population is heavily dependent on local resources unless there are livelihood alternatives that would improve human wellbeing and help safeguard forests and other natural resource exploitation. According to Abrams et al. [40], conservation success in African depends on capacity building that leads to a sense of ownership. Drawing from a Tanzanian example, Meroka and Haller [41] noted that despite the official discourse of collaborative conservation, for most local people, conservation for which they do not derive any direct economic benefit means underdevelopment. As the debate waged, DeFries et al. [42], in a counter view, noted that "win-win-win" opportunities are 
idealistic in many situations. They instead advocated for what they referred to as "small loss-big gain" opportunities. They explained this to mean a governance regime in which the ecological functioning of the protected area is maintained ("big gain") with minimum negative consequences for human land use ("small loss").

Embedded in the collaborative approach [7] is the notion of local perceptions and attitudes, which some have recognized as paramount to effective collaboration. Several authors have argued that successful PA governance requires not only local community collaboration but also changes in perceptions and attitudes of local people, which would engender the integration of local development with environmental conservation [43-45]. According to a review by Dimitrakopoulos et al. [45], perceptions and attitudes are influenced by the level of trust towards institutions responsible for governance and management, the restrictions imposed during the establishment of a PA, the level of awareness among citizens and the personal attributes of individuals.

Local attitudes towards PA management, according to Eagly and Chaiken [46], is a cognitive favoured or disfavoured evaluation of a PA, which reflects the beliefs that people hold about the PA. This, according to them, may be influenced by PA staff or management interventions, local economic needs and history, or other indirectly related socio-economic factors such as government policy. Perceptions, on the other hand, refer to people's beliefs that derive from their experiences and interaction with a programme or activity [47]. Xu et al. [43] argue that local people's perceptions are related to costs and benefits produced by PAs, their dependence on PA resources and their knowledge about PAs. According to Nicholas et al. [48], groups within the same region may even differ in their perceptions about the impacts of the same PA on them. Such differences in perception are mostly driven by economic dependence on ecosystem services [49]. Parker et al. [7] argued that improving relationships with local communities depends partly on identifying the perceived costs to the local communities and mitigating them, as well as identifying the perceived benefits and maintaining or enhancing them. This is in line with the argument of McNeely et al. [50] that local interest is dependent on the balance between the sacrifices local communities make and the benefits they derive from PAs. According to these authors, this interest often wanes when the opportunity costs of conservation far outweigh the foregone development alternatives or traditional activities.

In a nutshell, the model of Meffe et al. [34], explained different levels of collaboration and advocated for the ideal (win-win-win) solutions, where governance and management responsibility and authority are shared among multiple stakeholders and where benefits that accrue are equitably distributed to engender effective local collaboration. Though there were counter views to the collaborative model, it is also important to note that PA governance regime, to a large extent, influences local perceptions and attitudes towards PA management, which in turn is dependent on the economic and other benefits that local people derive from the conservation initiative.

\section{Materials and Methods}

\subsection{Site Description}

The study area encompasses selected protected areas within the major ecological zones of Ghana. The selected PA sites span the entire latitudinal landscape of the country from about latitude $5.0^{\circ} \mathrm{N}$ to about latitude $11.0^{\circ} \mathrm{N}$. The ecological zones, which correspond with the climatic regime, are characterized by a gradation of rainfall intensity from the north of the country to the south. Owusu and Waylen [51], for instance, recorded 10-year average rainfall values for the savannah ecological zone to the north as $1000 \mathrm{~mm}$, the forest savannah ecotone in the mid portions as $1200 \mathrm{~mm}$ and the forest zone to the south as $1600 \mathrm{~mm}$. A total of eight PAs were selected across these zones to ensure a fair representation of all the major zones. These include: Kakum National Park (Category II) and Atewa Range Forest Reserve (Category VI) in the forest zone; Kogyae Strict Nature Reserve (Category IA), Digya National Park (Category II) and Bui National Park (Category II) in the forest/savannah ecotone; and Mole National Park (Category II) and Gbele Resource Reserve (Category IV) in the savannah 
zone (Figure 2). The categorization is based on the standard IUCN definition [3]. All these PAs were established by a Legislative Instrument (LI 710, as amended) [52] and operate under a state-managed governance regime. The Wildlife Division of the Ghana Forestry Service appoints staff who manage the PAs, guided by comprehensive management plans, which are designed for each PA, based on the management category of the PA, the PA priorities and the local context.

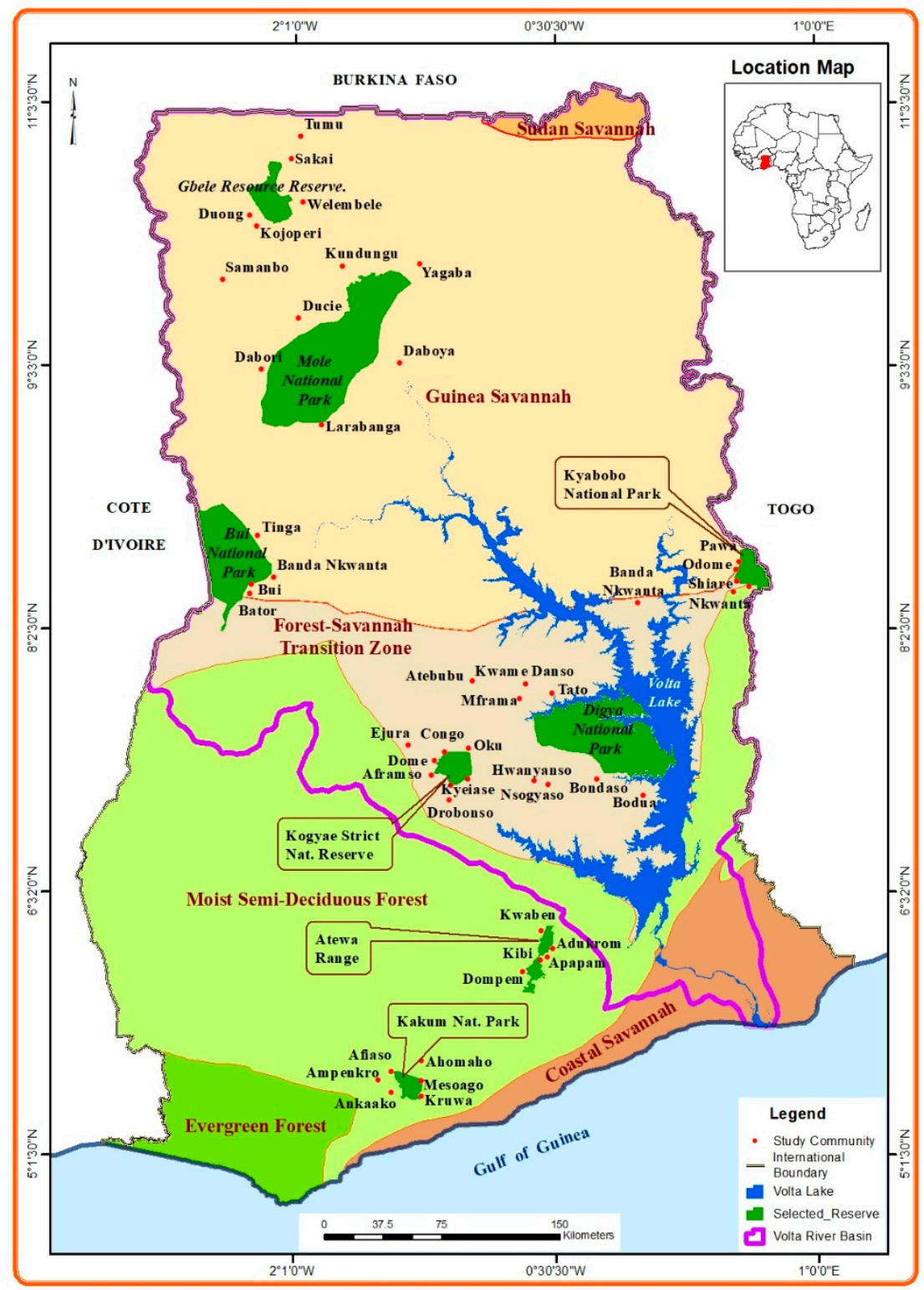

Figure 2. Map of Ghana and the Study Sites.

The selection of the sites was also based on the fact that all of the sites contain species of significant conservation value and are major hubs for in-situ biodiversity conservation. It is also worth noting that all six of the PAs outside the forest zone are located within the Volta Basin in Ghana, which is a major agricultural zone in the country [53]. It is believed that if effectively managed, these PAs would contribute to microclimate enhancement in the basin and impact positively on crop production [54] and the health of streams that feed the Volta River. Another important attribute of the basin is its strategic importance to Volta reservoirs, which supply about $50 \%$ of Ghana's electricity needs through hydro-electric power generation. A well-managed PA system within the basin would, therefore, 
help in environmental resilience building [55] and stabilize the Volta Basin against total degradation, considering the level of human activities taking place in the basin.

\subsection{Method}

Data for this research were gathered using focus group discussions (FGD), in-depth interviews with stakeholders and on-site inspections. Eight protected areas were selected for the study, and for each PA, an average of five (5) focus group discussions were held in the local communities. Local communities are here referred to as communities located within the neighborhood of the PAs whose livelihoods may be impacted directly or indirectly by the PA. The term local communities is used in this paper interchangeably with 'neighbouring communities' and 'nearby communities.'

Table 1 shows the names of the PAs surveyed, the total number of neighbouring communities, the number of FGDs held and the total number of participants across FGDs. Focus group discussions were held in 45 communities. Out of a total of 630 discussants, $73 \%$ were males and $27 \%$ females. Female participation was low because of cultural barriers in some of the communities, which do not encourage women to share information with strangers when their husbands are around. In several instances, separate discussions were organized for women to ensure their participation. The skewed gender representation did not affect the results, as all the responses from both males and females followed similar trends. The age of participants in the FGDs ranged between 17 and 95 years. Each FGD was made up of between five (5) and 15 individuals. The selection of participants was purposively done with the help of local opinion leaders to identify 'normal' residents who were of sound mind and knowledgeable about the subject matter.

Table 1. Focus Group Discussions in Respective Protected areas (PAs).

\begin{tabular}{|c|c|c|c|c|c|c|c|}
\hline \multirow{2}{*}{$\begin{array}{l}\text { Name of } \\
\text { PA }\end{array}$} & \multirow{2}{*}{$\begin{array}{c}\text { Area in } \\
\mathrm{Km}^{2}\end{array}$} & \multirow{2}{*}{$\begin{array}{c}\text { Total No. of Neighboring } \\
\text { Communities }\end{array}$} & \multirow{2}{*}{$\begin{array}{l}\text { No. of Com'ties where } \\
\text { FGDs Were Conducted }\end{array}$} & \multirow{2}{*}{$\begin{array}{l}\text { No. of } \\
\text { FGDs }\end{array}$} & \multicolumn{3}{|c|}{ No. of Discussants } \\
\hline & & & & & Males & Females & Total \\
\hline Atewa & 2323.0 & 29 & 4 & 4 & 27 & 2 & 29 \\
\hline Bui & 1821.0 & 37 & 5 & 5 & 49 & 22 & 71 \\
\hline Digya & 3478.0 & 64 & 9 & 11 & 101 & 38 & 139 \\
\hline Gbele & 546.9 & 20 & 5 & 6 & 59 & 27 & 86 \\
\hline Kakum & 360.0 & 64 & 6 & 6 & 61 & 22 & 83 \\
\hline Kyabobo & 399.0 & 7 & 5 & 5 & 54 & 15 & 69 \\
\hline Mole & 4840.0 & 33 & 4 & 4 & 33 & 26 & 59 \\
\hline Kogyae & 324.4 & 21 & 7 & 10 & 74 & 20 & 94 \\
\hline Totals & & 274 & 45 & 51 & 458 & 172 & 630 \\
\hline
\end{tabular}

Source: Fieldwork, 2016.

The discussions centered on the degree of local knowledge related to the PAs, the perceived relevance of PAs in the local context and the benefits derived from the PAs by local people. Issues regarding land tenure and compensation and how these influenced the attitudes of local people towards PA management were also discussed.

Individual in-depth interviews were conducted with 17 separate people made up of PA officials, community leaders and opinion leaders such as Local Assembly members. Whereas the interviews with the PA officials were to solicit information on the governance regime of the PAs, local collaboration and threats to the PAs, the local leaders were engaged to seek information on issues of land tenure and compensation, as well as their level of collaboration. In addition to the interviews, on-site inspections with Tour Guards of the Wildlife Division were carried out. Observations made included evidence of encroachment, disturbances by bush fires, evidence of crop raids by wild animals and land-use patterns along the fringes of the PAs.

Secondary data was sourced from published and unpublished books, scientific journals, project reports, workshop proceedings and Wildlife Division documented sources. These materials were sourced from libraries, online resources, government offices and institutional repositories. 
In data analysis, percentage responses were arrived at by tallying the collective responses received from 51 focus group discussions. Though the discussions covered several topical issues and individual contributions were varied, the flexibility of the methodology allowed for collective group responses to be tallied for each of the following issues:

1. main occupation of participants;

2. residential status;

3. benefits that community members derived from the PAs;

4. problems posed by PA establishment;

5. the likes and the dislikes of the communities with regard to PA management; and

6. the general community perceptions of protected areas.

For instance, on benefits, if there was a count of 21 out of the 51 groups listing tourism as a benefit, then tourism was given a score of $41.11 \%$ (i.e., $21 \div 51 \times 100$ ). The percentage values were calculated in this manner for each of the collective group responses, independent of each other.

\section{Results}

\subsection{Livelihood Profile of Neighbouring Communities}

The results of the field survey revealed that about $89 \%$ of respondents were primarily peasant farmers, while $11 \%$ were engaged in other occupations, including inland fishing, petty trading, charcoal production and local artisanal activities. Others combined occupations and engaged in activities such as beekeeping, shea butter production, mostly by women in the savannah territories and small livestock raising in almost all the households of the nearby communities.

Farm sizes within the communities were, on average, small ranging between 0.25 hectares and 2.0 hectares. A wide range of crops was cultivated, depending on the ecological zone. Table 2 shows the dominant cash crops cultivated by PA neighboring communities.

Table 2. Dominant cash crops.

\begin{tabular}{ccc}
\hline Protected Area & Ecological Zone & Dominant Cash Crops \\
\hline Atewa RFR & forest zone & cocoa, oil palm, cassava, maize and plantain \\
Bui NP & Forest-savannah ecotone & yam, maize and cassava, cowpeas, millet \\
Digya NP & Forest-savannah ecotone & yam, maize and cassava \\
Gbele & Savannah & peanut, millet, sorghum and maize \\
Kakum NP & forest & cocoa, oil palm, citrus, maize and cassava \\
Kogyae SNR & Forest-savannah ecotone & yam, maize and cassava, peanuts and cowpeas \\
Kyabobo & Forest-savannah ecotone & Yam, maize, cassava, peanuts cowpeas \\
Mole & Savannah & millet, maize, sorghum and yam \\
\hline
\end{tabular}

\subsection{Threats to $P A s$}

Threats are generally activities of human or natural origin that cause significant damage to PA resources, or are in serious conflict with the objectives of PA management [56]. Based on the findings from selected PA officials interviewed, threats to PAs in the study area can be categorized into underlying threats and proximate threats. The underlying threats were not directly visible or perceptible, but invariably were the main root causes of challenges faced by the PAs. These, according to our analysis, cut across all the PAs and linked to the socio-economic characteristics of the neighbouring communities, as well as the governance regime of the PAs. The underlying threats identified included: poverty in nearby communities, traditional land tenure system, a rapid rate of population growth and the state-managed governance type of the PAs.

Most participants considered themselves poor, marginalized and deprived. They bolstered their claim by alluding to the fact that as farmers, they lacked access to markets to sell their farm 
produce and therefore earn only meager incomes; they also lacked skills to find decent jobs outside their communities as most of them have little or no formal education. There were obvious signs of marginalization and deprivation among the people as basic amenities such as medical facilities, decent housing, pipe-borne water, decent sanitation and electricity were lacking in most of the communities.

On land tenure, it was observed that apart from the state-acquired lands that were designated as PAs, landholding was mainly by families, private individuals and community/clan heads. Government, therefore, has no control over areas adjacent to the PAs and could not regulate activities that fueled PAs isolation, such as farming and tree felling for fuel. Farm plots were visibly close to the PAs, leading to crop raids by wildlife and a high incidence of human-wildlife conflicts. Another important observation was that most of the communities visited $(62 \%)$ were predominantly migrant communities from other parts of Ghana, engaged in leased-hold farming arrangements with no long-term security over lands. They could not, therefore, cultivate perennial cash crops such as cocoa, oil palm and cashew because of tenure restrictions.

With regard to population growth, most participants agreed that populations had grown over the years, and that community members no longer have access to uncultivated areas to expand their farming activities. The fallow period for their farm plots has subsequently been reduced from five and six years to only two years, or only one farming season currently. There were, therefore, appeals to government to provide access to the PAs, where local farmers claimed the soils are more fertile.

The proximate threats, on the other hand, have a visible bearing on the PAs and directly affect the structure, composition, and functioning of the PAs. These threats and their associated impacts are mostly site-specific and presented in Table 3 . The threats are ranked according to their weighting by PA officials during interviews. Thus " 6 " represents the most severe threat to the PA while " 1 " represents the least threat.

Adjacent land use, small-scale mining and poaching were reported as the most severe threats followed by wildlife raids on farms, which affected local community support and required resources for compensation, and bush burning. The least threat reported was cross-border activities. With regard to individual protected areas, Atewa's greatest threat was illegal small-scale mining within and outside the reserve. The government of Ghana's decision to mine bauxite from the PA under a Chinese Synohydro deal tended to heighten this threat at the time of interviews. Adjacent land use by neighbouring communities and agricultural encroachment ranked second and third respectively, as most severe threats, while poaching was ranked as the least threat in Atewa. In the Bui National Park, illegal gold mining ranked as the highest threat, followed by the incidence of rampant bush burning, agricultural encroachment and conflicts between wildlife officials and some community members. The situation in Kogyae was least expected, as the strict PA had existing settlements within its boundaries. Adjacent land use followed as the second most severe threat in Kogyae, then annual bush burning and poaching. In the case of Mole National Park, the most severe threat was other forms of land use, notably farming and livestock grazing close to the PA, which tends to make the PAs isolated and increases their vulnerability. This was followed by wildlife poaching and elephants' raids on farms (Table 3). In Gbele Resource Reserve, group hunting, which could involve over 50 hunters at a time, was noted as a real threat particular to the Roan Antelope population. As detailed in the table, other protected areas had their respective threats, but it was observed that the differences in the severity of threats among the PAs were the result of differences in socio-economic and cultural circumstances of the neighbouring communities.

Further analysis of threats facing the PAs, as illustrated in Figure 3, indicates that adjacent landuse had a total score of 35 , being the most serious threat, followed by poaching with a score of 25 and annual bush burning, which scored 21. Illegal small-scale mining and conflicts between PA officials and community members were also noted as threats, with cross border issues involving nationals from neighboring countries and cattle grazing noted as the least serious of the threats. 
Table 3. Ranking of Proximate Threats to Protected Areas.

\begin{tabular}{|c|c|c|c|c|c|c|c|c|}
\hline \multirow{2}{*}{$\begin{array}{c}\text { Threat } \\
\text { Ranking }\end{array}$} & \multicolumn{8}{|c|}{ Protected Areas and Respective Threats } \\
\hline & $\begin{array}{l}\text { Atewa Range } \\
\text { Forest Reserve }\end{array}$ & Bui National Park & $\begin{array}{c}\text { Digya National } \\
\text { Park }\end{array}$ & $\begin{array}{c}\text { Gbele Resource } \\
\text { Reserve }\end{array}$ & $\begin{array}{c}\text { Kakum National } \\
\text { Park }\end{array}$ & $\begin{array}{c}\text { Kyabobo National } \\
\text { Park }\end{array}$ & $\begin{array}{c}\text { Kogyae Strict } \\
\text { Nature Reserve }\end{array}$ & $\begin{array}{c}\text { Mole National } \\
\text { Park }\end{array}$ \\
\hline 6 & Mining $^{1}$ & $\begin{array}{l}\text { Illegal small-scale } \\
\text { gold mining }\end{array}$ & Illegal entry ${ }^{2}$ & Poaching & Adjacent landuse & Adjacent landuse & $\begin{array}{c}\text { Settlements } \\
\text { inside the PA }\end{array}$ & $\begin{array}{l}\text { Adjacent } \\
\text { landuse }\end{array}$ \\
\hline 5 & $\begin{array}{l}\text { Adjacent } \\
\text { landuse }\end{array}$ & $\begin{array}{l}\text { Community/wildlife } \\
\text { officials' conflict }\end{array}$ & Bush burning & $\begin{array}{l}\text { Annual bush } \\
\text { burning }\end{array}$ & Elephant raids & Poaching & $\begin{array}{l}\text { Adjacent } \\
\text { landuse }\end{array}$ & Poaching \\
\hline 4 & $\begin{array}{l}\text { Agricultural } \\
\text { encroachment }\end{array}$ & $\begin{array}{l}\text { Annual bush } \\
\text { burning }\end{array}$ & $\begin{array}{c}\text { Agricultural } \\
\text { encroachment }\end{array}$ & $\begin{array}{l}\text { Adjacent } \\
\text { landuse }\end{array}$ & Poaching & $\begin{array}{l}\text { Community/wildlife } \\
\text { officials' conflict }\end{array}$ & $\begin{array}{c}\text { Annual } \\
\text { bushfires }\end{array}$ & Elephant raids \\
\hline 3 & Logging & Adjacent landuse & $\begin{array}{l}\text { Community/wildlife } \\
\text { officials' conflict }\end{array}$ & $\begin{array}{l}\text { Settlements }{ }^{3} \\
\text { inside the PA }\end{array}$ & Logging & $\begin{array}{l}\text { Wildlife raids on } \\
\text { farms }\end{array}$ & Poaching & $\begin{array}{l}\text { Annual bush } \\
\text { burning }\end{array}$ \\
\hline 2 & Poaching & $\begin{array}{c}\text { Settlements inside } \\
\text { the PA }\end{array}$ & Cattle grazing & $\begin{array}{l}\text { Cross border } \\
\text { issues }\end{array}$ & $\begin{array}{l}\text { Community/wildlife } \\
\text { officials' conflict }\end{array}$ & $\begin{array}{l}\text { Non-payment of land } \\
\text { compensation }\end{array}$ & $\begin{array}{l}\text { Wildlife raids } \\
\text { on farms }\end{array}$ & \\
\hline 1 & & Cross border issues & Elephant raids & & & Cross border issues & & \\
\hline
\end{tabular}

of settlements inside the PA. ${ }^{3}$ The settlers have accepted to be resettled by March 2020. 


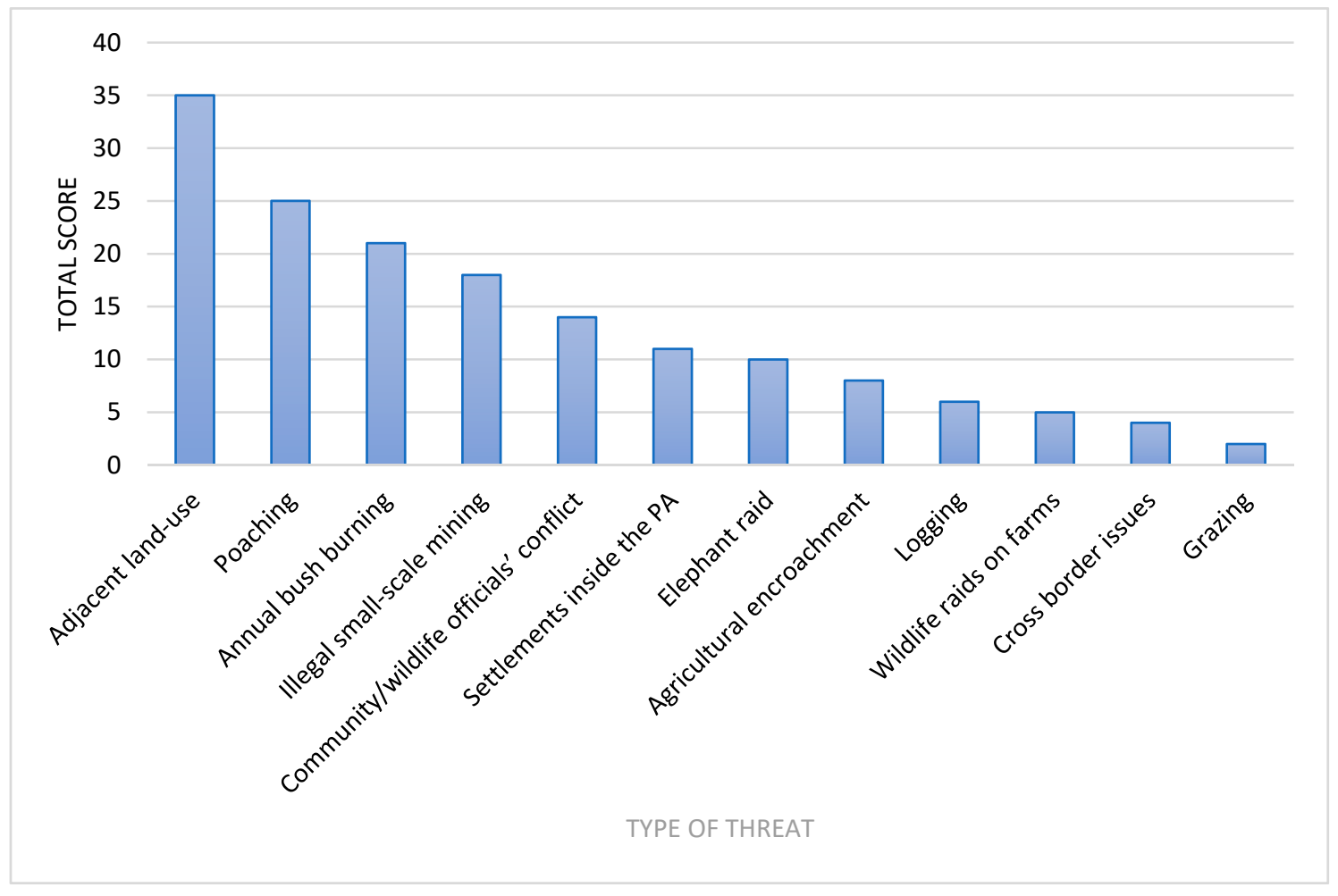

Figure 3. Analysis of Threats Facing Neighboring Communities of Protected Areas.

The threat situation from the results and analysis indicate that livelihood issues constitute the biggest threat to PAs in developing economies such as Ghana. It is evident that the underlying causes of these livelihood issues (or proximate threats) are poverty, the traditional landholding system, surging populations in nearby communities and absolute state control over protected areas, as revealed during fieldwork.

\subsection{Influence of Governance on Management Effectiveness}

Neighbouring community members complained bitterly about the highhandedness of PA officials and how petty offenses were criminalized. Some of the FGD participants vowed never to cooperate with the officials in the management of the sites because of these tensions and because they derived no real benefits. This situation posed a significant drawback for the collaborative management of these areas. Several instances of conflicts between PA officials and local community members were cited during the interviews. Digya National Park management, for instance, had, on several occasions, resorted to forced evictions of squatters from the park, the last one being in 2005 when nine squatters reportedly lost their lives on the Volta Lake through a boat accident. People from Kruwa, a neighboring farming community to Kakum National Park, had seriously resented the PA officials due to incessant crop raids by wildlife on their farms. The Shari community bordering Kyabobo National Park reportedly gunned down a PA official in 2003 while he was on patrol duties, as well as other instances of PA officials turning their arms on poachers, such as the case in Banda Nkwanta in Bui National Park in 2004, have all been documented [57]. Thus, in general terms, the relationship between PA officials and community members was largely not very cordial, partly because the state governance regime failed to recognize and collaborate with neighbouring communities. During one of the FDGs, a 22-year-old farmer in a village near Kogyae Strict Nature Reserve had this to say:

"Wildlife guards sometimes posed as friends to us, to the extent of begging us for food. They are, however, very highhanded on us whenever we kill animals that stray into our farms. When arrested, 
they usually tied our hands with ropes and gave us several lashes of cane before we were released." (Fieldwork, 2016).

The Wildlife Division is, however, making frantic efforts to increase community education to improve their relationship with local communities. In Kakum, Mole and Kyabobo National Parks, community collaborative units such as Community Development Unit (CDU), Protected Area Management Advisory Units (PAMAUS), Protected Area Management Advisory Board (PAMAB) and Community Resource Management Areas (CREMAs) are being established to enhance effective communication between local people and PA officials. Unfortunately, investigations during field interviews suggested that such collaborative schemes are only successful when supported by donor funding.

The analysis from the FGDs and interviews suggest that the governance regime of the protected areas is a major determinant of the level of local support for the PAs. In the case of formal PAs such as national parks and resource reserves, which are exclusively under state control, local participation becomes very limited as the state establishes units within the Wildlife Division such as law enforcement units, patrol units and camps for PA officers, all with the aim of excluding the local people without regard to the IUCN's PA management categories, some of which allowed human activities on a limited scale. This, more often than not, negatively influences local perceptions and attitudes.

\subsection{Benefits Derived by Local People from Establishment of Protected Areas}

Collective responses received from participants at the 51 FDGs showed that $76 \%$ of the communities claimed they derived some benefits from the establishment of the PA, while $24 \%$ claimed they did not. It should, however, be noted that the apparent high percentage value scored as benefits is only relevant to the local communities if those benefits help in the enhancement of their economic livelihood conditions. Further analysis of the benefits revealed that those who derived benefit from bush meat scored the highest percentage of $52 \%$, followed by employment benefits $45 \%$, enhancement of micro-climate $42 \%$, and the satisfaction derived from seeing wildlife species $40 \%$ (Figure 4). Benefits which scored $30 \%$ and below were tourism, sustainable fishing along the Volta lakeshores, the bequest value of the PAs, support for alternative livelihood activities, spiritual satisfaction and access to non-timber forest products (NTFPs).

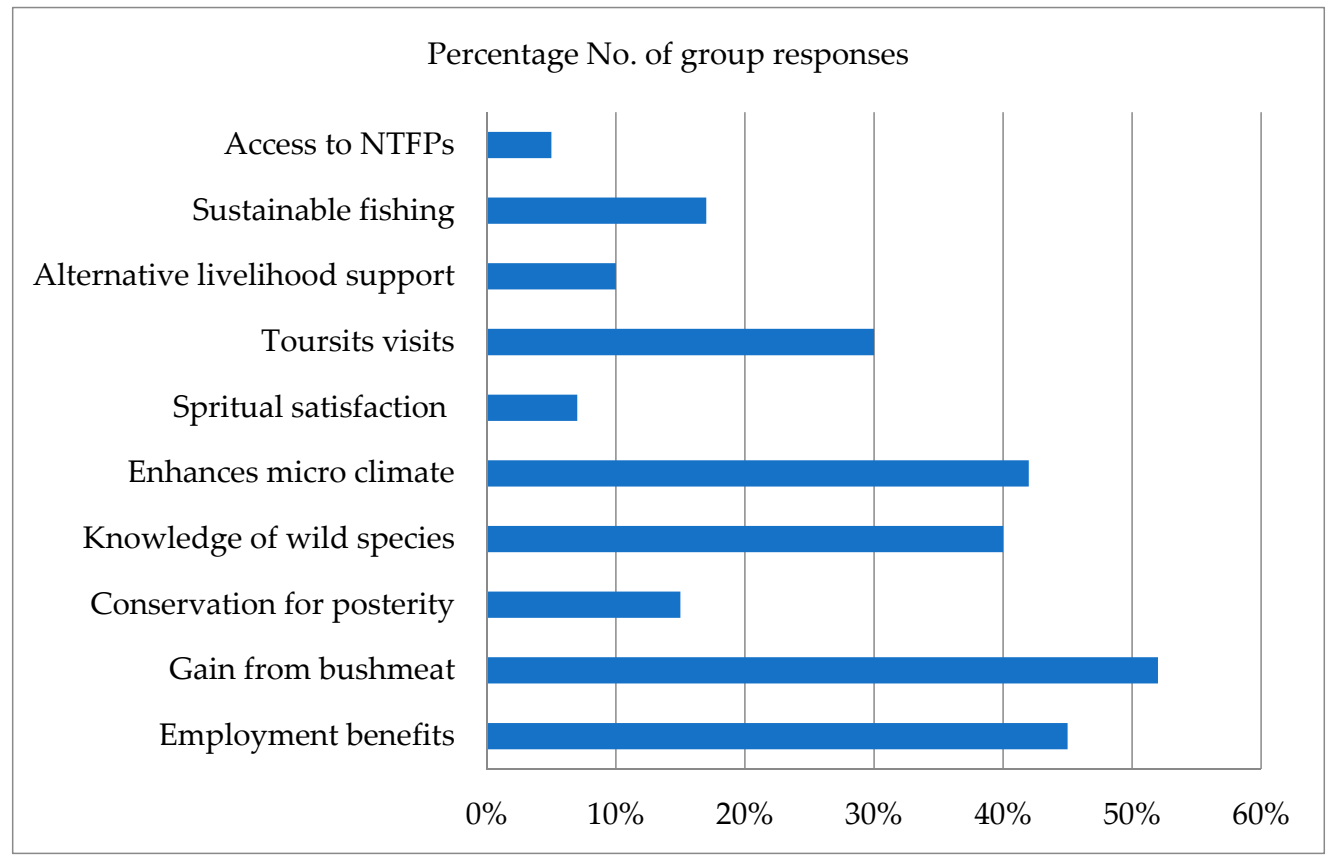

Figure 4. Benefits derived by Communities from the PAs. Source: Fieldwork (2016). 
Participants who claimed they benefited from tourism explained that though they derived no economic benefits, they felt delighted seeing tourists in their communities. A few lakeshore community members in Digya National Park enclave bordering the Volta Lake claimed that they derived benefits from sustainable fishing by virtue of the high productivity experienced near portions of the lake under protection. In Kyabobo, some community members claimed they benefited from donor-supported alternative livelihood activities such as beekeeping and oil palm nursery establishment in the recent past. The benefits derived from a PA tend to shape one's perception and attitude towards that establishment, but this is also dependent on the governance regime of the PA. So in a situation where absolute state control is exercised, local benefits may not meet general expectations to resolve livelihood challenges.

\subsection{Problems Imposed by PA Establishment on Neighbouring Communities}

Most of the local communities living close to PAs felt either disadvantaged or considered the establishment of the PA as being a problem to them. From the findings, the most serious problem listed, with a score of $60 \%$, was crop raids by wild animals from the reserves (Figure 5). This was followed by a lack of access to bushmeat (35\%) and highhandedness on the part of PA officials (30\%). Other problems enumerated included loss of fishing grounds with regard to those along the lakeshores, lack of access to NTFPs, restricted access to mineral deposits in Bui and Atewa, and loss of fertile lands.

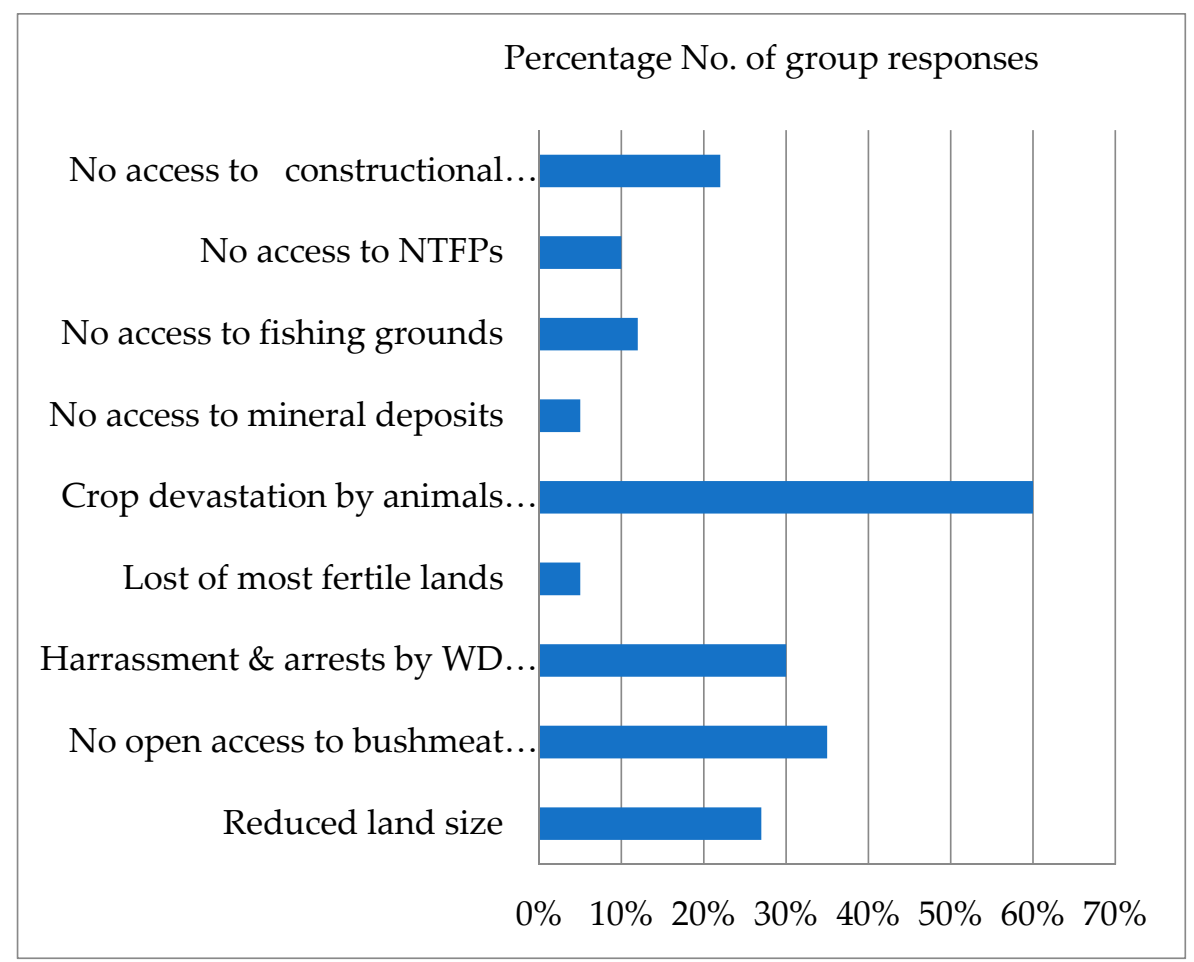

Figure 5. Problems imposed by a PA Establishment. Source: Fieldwork, (2016).

Wildlife raids on farms were one of the major problems faced by the neighbouring communities from their perspective. Elephant raids, in particular, were reportedly very devastating and most common in the vicinities of Kakum, Mole and the southern fringes of Digya. Other animals such as rodents, primates and angulates were reported to cause serious havoc to farm crops, which was a major source of conflict between PA officials and local communities.

When these results are compared to the analysis of threats, an interesting observation was made. The two most severe threats from the point of view of PA managers and administrators were adjacent land use and poaching. At the same time, the two highest-ranking problems, as reported by the local communities, were crop devastation by wildlife and lack of access to bushmeat. These two pairs of 
issues mirror each other. Indeed, it was noted that areas bordering the PAs were either communal lands or belonged to individual families. These adjacent lands were mostly under farming, and these farms get exposed to raids by wildlife from the PAs. Farmers' reaction to wildlife raids was mostly poaching, which unfortunately is illegal, thus bringing the communities into conflict with PA officials. From the point of view of the administrators, therefore, poaching was a serious threat, while local communities regarded their restricted access to bushmeat as a serious problem. Under such circumstances, local perceptions and attitudes would be that of resentment and/or passivity.

\subsection{Community Perception of the Establishment of PAs}

Based on the responses received on benefits derived from, and problems imposed by the PAs on the communities, the question was posed as to the extent to which neighboring communities supported the establishment of the PAs. From the responses, 50\% claimed they supported the PA concept, while $35 \%$ claimed they did not support the concept. The remaining 15\% remained indifferent.

Out of the total percentage which did not support the establishment of PAs, $86 \%$ responded that crop destruction by wild animals was a problem for them. Again, $79 \%$ of the groups that dislike the idea of PA establishment claimed that PA officials had manhandled them or their relations. Within the same group who dislike the PA concept, 57\% reported reduced farm sizes as the reason for this view. A further $23 \%$ of those who did not support the PA establishment expressed intense hatred towards PA officials. All communities whose farms were raided by elephants were emphatic that they dislike the concept of PA establishment. These communities constituted $36 \%$ of the total number of groups that disliked PA establishment. Table 4 is a summary of the above analysis showing a comparison between the percentage of respondents who disliked the PA concept and those who supported it.

Table 4. Problems Imposed by PA Establishment and Community Attitudes towards PA Establishment.

\begin{tabular}{ccc}
\hline Problems Imposed by PA Establishment & $\begin{array}{c}\text { Percentage of Those Who } \\
\text { Dislike PA Establishment }\end{array}$ & $\begin{array}{c}\text { Percentage of Those Who } \\
\text { Accept PA Establishment }\end{array}$ \\
\hline Crop destruction by animals & $86 \%$ & $65 \%$ \\
Frequent manhandling by WD officials & $79 \%$ & $15 \%$ \\
Reduced land size & $57 \%$ & $60 \%$ \\
\hline
\end{tabular}

All the groups that accepted the PA establishment claimed they had received some education from PA officials, who explained to them the reasons for the PA establishment. They indicated their willingness to serve as informants against poaching, especially by strangers, and as firefighting volunteers when motivated to do so.

It is clear from the results that the state-management PA governance type, which dominates much of Ghana's conservation landscape, operates where enforcement and regulation dictate decision-making and, in a way, tends to exclude the local people. There is, therefore, little local community collaboration in the state-managed PAs system, which contravenes the multi-stakeholder approach needed for conservation success. Furthermore, the system of land tenure where individual land rights prevail does not make landscape management a feasible option, so long as land remains a major source of livelihood in sub-Saharan countries such as Ghana.

\section{Discussion}

The findings showed that poverty in nearby communities, land tenure issues, increasing human populations and the system of PA governance were the main underlying issues that are fueling the myriads of challenges faced by PAs in Ghana. As indicated in the findings, indicators such as non-availability of medical facilities, quality education, decent housing, pipe-borne water, proper sanitation and electricity are lacking in most of the study communities. This lack of essential services is reflected in a poverty index of 0.261 for rural Ghana [58], which directly applies to most of the neighboring communities studied. This finding concurs with some earlier works, for example, Ayivor 
et al. [59], which ranked poverty in nearby communities as the most serious threat facing PAs in Ghana. This situation supports the views expressed in the broader conservation literature that PAs do not reduce poverty in nearby communities since the primary objective of their establishment is not human-centered, but to conserve biological diversity [18,28]. Tackling this issue requires multi-stakeholder collaboration, such as support from development agencies and the private sector, to promote pro-poor livelihood programs aimed at reducing poverty in these areas and household reliance on local natural resources.

On human population growth, the main issue of concern is not the national annual growth rate of $2.2 \%$ [60], but the fact that $89 \%$ of the neighboring communities were farmers who depended on limited land space for livelihood. Thus, any increase in population puts more pressure on the PAs through adjacent land-use. This is noteworthy, as the expansion in individual farms that share borders with the PAs can result in PA isolation in the absence of matrix-based conservation. Since most of the PA sizes are small, wildlife with a wide range, such as the elephant, invade farms within their range, resulting in farmer-wildlife conflict [57]. Studies in Cameroon, for instance, indicated that elephant raids accounted for about 70\% loss of family production [61]. Several studies have shown that when neighboring communities are forced to absorb the costs of living with wildlife, local collaboration in PA management may be seriously undermined $[10,62,63]$. The results of this assessment showed that $86 \%$ of those who had experienced crop raids by wildlife, including elephants, claimed that they did not support the PA concept. As Naughton et al. [64] noted, human-wildlife conflicts remain a major obstacle to community support for conservation. This requires the establishment of another form of a compensation system, besides the existing land compensation, to appease those whose farms are raided by elephants in particular. Ogra and Badola [63] conceptualized this type of compensation as being more closely based on ground-level realities, which implies that farmers whose crops are raided by wildlife should be compensated anytime such raids occur.

The governance type prevailing in all the PAs studied is the state-managed type in which decision making is centralized and the approach largely "exclusive." This approach, as earlier noted, puts a higher premium on ecological considerations than local community welfare. Meffe et al. [34] referred to this approach as regulatory enforcement and regulation dictating decision-making. The forced eviction of settlers from Digya National Park by PA officials because their activities did not promote the ecological integrity of the park is an outcome of such a state-controlled governance type [57]. According to Cernea and Schmidt-Soltau [65], who based their argument on the "Impoverishment Risks and Reconstruction Model," if PAs achieve additional degrees of conservation, part of the cost is paid in the coin of additional impoverishment for the people violently uprooted from their habitat and not resettled. Thus, operating only within the "ecological and institutional context" [34] would result in poverty in nearby communities. This is the likely reason why about $50 \%$ of the local communities did not support the concept of PA establishment and would not collaborate in their management.

With regard to socio-economic benefits, a closer look at three out of the four listed benefits that had scores of at least $40 \%$ (i.e., microclimate enhancement, knowledge of wild animals and benefits from bushmeat), clearly shows that in real terms, two were intangible benefits. More so, benefits from bushmeat were illegitimate because the activity was illegal, and people caught engaging in it were criminalized and punished. The issue of high handedness by PA officials on PA offenders, however, tends to undermine the spirit of collaboration. According to Stern [66], such people who feel unwanted will do everything to outwit PA officials whom they consider as "police." Concerning employment benefits, which scored relatively high, the real situation observed was that most of the local beneficiaries were only engaged seasonally as casual laborers to clear boundary lines, or to serve as tour guards, and earned only meager wages. It should be noted that in protected area management within the Africa context, any small percentage number of people that oppose PA establishment may have more than proportionate repercussions on PA goals and objectives. For instance, it takes only one or two people to initiate bush fires in a PA, which generally causes serious havoc to wildlife on an annual basis. This was the experience of Digya National Park and Gbele Resource Reserve (Table 3), 
where the perpetrators were never identified. Furthermore, in Gbele Resource Reserve, where group hunting was observed as a serious threat, it takes less than $10 \%$ of the population to perpetrate this act, but the impacts are grievous.

The research suggests that nature conservation, mainly where governance is vested in the state, does not bring enough economic benefits to local people and may result in conflicts because giving access to the local people to exploit the economic resources of the PA is seen to compromise the ecological integrity of the ecosystem being protected. However, since poverty levels are high in the neighbouring communities as evident in the findings, the communities placed a greater premium on economic benefits than other benefits and, thus, not appreciative of intangible benefits since these did not enhance their economic livelihood conditions. As a solution, Meffe et al. [34], suggested meeting the interest of multiple stakeholders by operating within the converging point of "socio-economic context" and "institutional context," which they referred to as "win-win-win" partnerships. This converging point represents collaborative management in which stakeholders of the economic context, ecological context and institutional context combine their interests in the management of the protected areas such that none of the three becomes unduly disadvantaged. Such collaboration would assure the local communities that their rights are respected and would thus, engender their support for the effective management of the protected areas.

\section{Conclusions}

It is obvious from the discussion that the state-managed PA governance regime does not meet local livelihood needs and is, therefore, perceived by most local communities as an initiative by governments to conserve nature for the benefit of the state. The governance regime, thus, fails to address poverty in nearby communities and tends to ignore fundamental problems that confront the local people such as human-wildlife conflicts. The regime has instead fueled antagonistic relationships between the communities and PA officials, resulting in highhandedness on the part of officials and criminalization of livelihood-related offences that are committed by the local people. This implies that PA officials will continue to regard local community members as intruders rather than partners because the governance regime does not engender true local collaboration. Promotion of co-managed protected areas is an option that would enhance community ownership and ensure better collaboration and greater success in nature conservation. Furthermore, for the state-controlled areas to be effectively managed, every effort must be made to positively influence local perceptions and attitudes towards behavioral change by promoting collaborative partnerships among the local people and all other interest groups. The promotion of village committees such as the Community Resource Management Area (CREMA) concept, which is an initiative instituted by the Ghana Forestry Commission, provides local people with an open forum to discuss issues, ask questions, and recommend their own prescriptions. This initiative has started receiving recognition and, therefore, is being implemented in some of Ghana's state-managed PAs. It is further recommended that PA officials need to solicit donor support or additional funding from their governments to promote local collaboration and alternative livelihood activities, which comes at a high cost. This study also recommends a new system of compensation that is oriented towards permanent job creation through development interventions in the neighboring communities to empower the local people economically to help alleviate poverty in these communities. There is also the need to consider integrated landscape management as an option where wildlife will be protected not only in designated reserves but within the entire landscape through multi-stakeholder engagement. Effective use of the landscape in a manner that optimizes yields such as agricultural intensification can also reduce pressure on PAs.

Author Contributions: Conceptualization, J.S.A.; Data curation, J.S.A.; Formal analysis, J.S.A., J.K.N. and S.A.; Investigation, J.S.A., J.K.N. and S.A.; Methodology, J.S.A., J.K.N. and S.A.; Writing-original draft, J.S.A., J.K.N. and S.A.; Writing-review \& editing, J.S.A., J.K.N. and S.A. All authors have read and agreed to the published version of the manuscript.

Funding: This research received no external funding. 
Acknowledgments: The authors wish to thank the Wildlife Division of the Ghana Forestry Commission for granting us access to all the protected areas to carry out fieldwork. We wish also to thank all the protected area managerial staff for their support during fieldwork and for the valuable information provided during interview sessions. A note of appreciation also goes to all the local chiefs of the communities visited, for allowing us entry into the communities and encouraging the community members to participate in the focus group discussions. Above all, we thank the Almighty God for the guidance and protection during the entire duration of the work.

Conflicts of Interest: The authors declare no conflict of interest.

\section{References}

1. Joppa, L.N.; Loarie, S.R.; Pimm, S.L. On the protection of "protected areas". Proc. Natl. Acad. Sci. USA 2008, 5, 6673-6678. [CrossRef] [PubMed]

2. Chapes, S.; Spalding, M.; Jenkins, M. The World's Protected Areas: Status, Values and Prospects in the 21st Century; University of California Press: Berkeley, CA, USA, 2008; pp. 1-359.

3. Dudley, N. (Ed.) Guidelines for Applying Protected Area Management Categories; IUCN: Gland, Switzerland, 2008; pp. 1-86.

4. Meine, C.D. The oldest task in human history. In A New Century for Nature Resources Management; Knight, L.R., Bates, S.F., Eds.; Island Press: Washington, DC, USA, 1995; pp. 7-35.

5. Uphoff, N. Learning from Gal Oya: Possibilities for Participatory Development and Post-Newtonian Science; Cornell University Press: Ithaca, NY, USA, 1992; pp. 1-448.

6. Schelhas, J.; Buck, L.E.; Geisler, C.C. The challenges of Adaptive Collaborative management. In Biological Diversity. Balancing Interest through Adaptive Collaborative Management; Buck, L., Geisler, C.C., Shelhas, J., Wollenberg, E., Eds.; CRC Press: Boca Raton, FL, USA; London, UK; New York, NY, USA; Washington, DC, USA, 2001.

7. Parker, P.; Rollins, R.; Murray, G.; Chafey, A.; Cannessa, R. Community perceptions of the contributions of parks to sustainability in Canada. Leisure/Loisir 2017, 41, 365-389. [CrossRef]

8. Wells, M.; Brandon, K. People and Parks. Linking Protected Area Management with Local People; The International Bank for Reconstruction and Development/the World Bank: Washington, DC, USA, 1992; pp. 1-99.

9. Kramer, R.; van Schaik, C.; Johnson, J. Last Stand: Protected Areas and the Defense of Tropical Biodiversity; Oxford University Press: Oxford, UK, 1997; pp. 1-242.

10. Brandon, K.; Redford, K.H.; Sanderson, S.E. (Eds.) Parks in Peril. People, Politics and Protected Areas; Island Press: Washington, DC, USA, 1998; pp. 1-499.

11. Oates, J.F. Myth and Reality in the Rainforest: How Conservation Strategies are Failing in Africa; University of California Press: Berkeley, CA, USA, 1999; pp. 1-338.

12. Anthony, B. The dual nature of parks: Attitudes of neighbouring communities towards Kruger National Park, South Africa. Environ. Conserv. 2007, 34, 236-245. [CrossRef]

13. Andrade, G.S.M.; Rhodes, J.R. Protected areas and local communities: An inevitable partnership toward successful conservation strategies? Ecol. Soc. 2012, 17, 14-29. [CrossRef]

14. Stone, M.T.; Nyaupane, G.P. Protected areas, tourism and community livelihoods linkages: A comprehensive analysis approach. J. Sustain. Tour. 2016, 24, 673-693. [CrossRef]

15. Lindenmayer, D.B.; Franklin, J.F. (Eds.) Towards Forest Sustainability; Island Press: Washington, DC, USA; CSIRO Publishing: Clayton, VIC, Australia, 2003.

16. Buhumuza, M.; Balkwill, K. Factors affecting the success of conserving biodiversity in national parks: A review of case studies from Africa. Int. J. Biodivers. 2013. [CrossRef]

17. Das Kanti, B. Role of NTFPs among forest villagers in a protected area of West Bengel. J. Hum. Ecol. 2005, 18, 129-136.

18. Scherl, L.M.; Wilson, A.; Wild, R.; Blockhus, J.M.; Franks, P.; McNeely, J.A.; McShane, T. Can Protected Areas Contribute to Poverty Reduction? Opportunities and Limitations; IUCN: Gland, Switzerland; Cambridge, UK, 2004; Volume 4, pp. 1-60.

19. IFAD (International Fund for Agricultural Development). Improving Access to Land and Tenure Security; Policy IFAD: Rome, Italy, 2008; 42p.

20. Hitt, M.A.; Black, S.; Porter, L.W. Management, 3rd ed.; Pearson Education: Upper Saddle River, NJ, USA, 2011. 
21. Worboys, G.L.; Trzyna, T. Managing protected areas. In Protected Area Governance and Management; Worboys, G.L., Lockwood, M., Kothari, A., Feary, S., Pulsford, I., Eds.; ANU Press: Canberra, Australia, 2015; pp. 207-250.

22. UNEP-WCMC. Protected Areas and Biodiversity; UNEP-WCMC Biodiversity Series No. 21; UNEP-WCMC: Cambridge, UK, 2004.

23. Borrini-Feyerabend, G.; Kothari, A.; Oviedo, G. Indigenous and Local Communities and Protected Areas: Towards Equity and Enhanced Conservation; IUCN: Gland, Switzerland; Cambridge, UK, 2004; pp. 1-111.

24. West, P.C.; Brechin, S.R. Resident Peoples and National Parks: Social Dilemmas and Strategies in International Conservation; University of Arizona Press: Tucson, AZ, USA, 1991; pp. 1-443.

25. Adams, W.; Hulme, D. If community conservation is the answer in Africa, what is the question? Orynx 2001, 35, 193-200. [CrossRef]

26. Ghimire, K.B.; Pimbert, M.P. Social Change and Conservation: Environmental Politics and Impact on National Parks and Protected Areas; Earthscan Publications: London, UK, 1997; pp. 1-352.

27. Lewis, D.; Carter, N. (Eds.) Voices from Africa: Local Perspective on Conservation; WWF-US: Washington, DC, USA, 1993.

28. Brechin, S.R.; Wilshusen, P.R.; Fortwangler, C.L.; West, P. Contested Nature: Promoting International Biodiversity with Social Justice; SUNY Press: New York, NY, USA, 2003; pp. 1-315.

29. World Wildlife Fund (WWF). Stakeholder Collaboration: Building Bridges for Conservation; World Wildlife Fund: Washington, DC, USA, 2000; Available online: www.worldwildlife.org (accessed on 20 July 2019).

30. Mulongoy, K.J.; Chape, S. Protected Areas and Biodiversity: An Overview of Key Issues; CBD Secretariat and UNEP-WCMC: Montreal, QC, Canada; Cambridge, UK, 2004; pp. 1-55.

31. DeCaro, D.; Stokes, M. Social-psychological principles of community-based conservation and conservancy motivation: Attaining goals within an autonomy-supportive environment. Conserv. Biol. 2008, 22, 443-1451. [CrossRef]

32. Kemmis, D. Community and the Politics of Place; University of Oklahoma Press: Norman, OK, USA, 1993; pp. 1-150.

33. Daily, G.C.; Ellison, K. The New Economy of Nature and the Marketplace: The Quest to Make Conservation Profitable; Island Press: Washington, DC, USA, 2002; pp. 1-260.

34. Meffe, G.; Nielsen, L.; Knight, R.; Schenborn, D. Ecosystem Management: Adaptive, Community-Based Conservation; Island Press: Washington, DC, USA, 2002; pp. 1-333.

35. Rosenzweig, M. Win-Win Ecology: How the Earth's Species Can Survive in the Midst of Human Enterprise; Oxford University Press: Oxford, UK, 2003; pp. 1-224.

36. Feurt, C. Protecting Our Children's Water-Using Cultural Models and Collaborative Learning to Frame and Implement Ecosystem Management. Ph.D. Thesis, Antioch University-New England, Keene, NH, USA, 2007.

37. Chicchon, A. Conservation theory meets practice. Conserv. Biol. 2000, 14, 1368-1369. [CrossRef]

38. Cooke, B.; Kothari, U. Participation: The New Tyranny? Zed Books: London, UK, 2001; pp. 1-207.

39. Terborgh, J.; van Schaik, C.; Davenport, L.; Rao, M. Making Parks Work: Strategies for Preserving Tropical Nature; Island Press: Washington, DC, USA, 2002; pp. 1-511.

40. Abrams, R.W.; Anwana, E.D.; Ormsby, A.; Dovie, D.B.K.; Ajagbe, A.; Abrams, A. Integrating top-down with bottom-up conservation policy in Africa. Conserv. Biol. 2009, 23, 799-804. [CrossRef] [PubMed]

41. Meroka, P.; Haller, T. Government wildlife, unfulfilled promises and business: Lessons from participatory conservation in the Selous Game Reserve, Tanzania. In People, Protected Areas and Global Change: Participatory Conservation in Latin America, Africa, Asia and Europe; Galvin, M., Haller, T., Eds.; Geogra-Bernensia: Bern, Switzerland, 2008; Volume 3, pp. 177-221.

42. DeFries, R.S.; Foley, J.A.; Asner, G.P. Land use choices: Balancing human needs and ecosystem function. Front. Ecol. Environ. 2004, 2, 249-257. [CrossRef]

43. Xu, J.; Chen, L.; Lu, Y.; Fu, B. Local people's perceptions as decision support for protected area management in Wolong Biosphere Reserve. J. Environ. Manag. 2006, 78, 362-372. [CrossRef]

44. Eben, M. Public participation during site selections for Natura 2000 in Germany: The Bavarian Case. In Stakeholder Dialogues in Natural Resources Management; Stoll-Kleemann, S., Welp, M., Eds.; Springer: New York, NY, USA, 2007; pp. 261-278. 
45. Dimitrakopoulos, P.G.; Jones, N.; Iosifides, T.; Florokapi, I.; Lasda, O.; Paliouras, F.; Evangelinos, K.I. Local attitudes on protected areas: Evidence from three Natura 2000 wetland sites in Greece. J. Environ. Manag. 2010, 91, 1847-1854. [CrossRef] [PubMed]

46. Eagly, A.H.; Chaiken, S. Attitude structure and function. In The Handbook of Social Psychology; Gilbert, D.T., Fiske, S.T., Lindzey, G., Eds.; McGraw-Hill: New York, NY, USA, 1998; Volume 1, pp. 269-322.

47. Htun, N.Z.; Mizoue, N.; Yoshida, S. Determinants of local people's perceptions and attitudes toward a protected area and its management: A case study from Popa Mountain Park, Central Myanmar. Soc. Nat. Resour. 2012, 25, 743-758. [CrossRef]

48. Nicholas, L.N.; Thapa, B.; Ko, Y.J. Resident's perspectives of a world heritage site: The Pitons management area, St. Lucia. Ann. Tour. Res. 2009, 36, 390-412. [CrossRef]

49. Bennett, N.J.; Dearden, P. Why local people do not support conservation: Community perceptions of marine protected area livelihood impacts, governance and management in Thailand. Mar. Policy 2014, 44, 107-116. [CrossRef]

50. McNeely, J.A.; Miller, K.R.; Reid, W.V.; Mittermeier, R.A.; Werner, T.B. Conserving the World's Biological Diversity; IUCN: Gland, Switzerland, 1990; pp. 1-193.

51. Owusu, K.; Waylen, P. Trends in spatio-temporal variability in annual rainfall in Ghana (1951-2000). R. Meteorol. Soc. 2009, 64, 115-120. [CrossRef]

52. Attuquayefio, D.K.; Fobil, J.N. An overview of biodiversity conservation in Ghana: Challenges and prospects. West Afr. J. Appl. Ecol. 2005, 7, 1-18. [CrossRef]

53. Titriku, P.K. Agriculture in the Volta Basin: Problems and prospects. In Sustainable Integrated Development of the Volta Basin; Gordon, C., Ametekpor, J.K., Eds.; VBRP, Gold Type Press: Accra, Ghana, 1999; pp. 107-117.

54. Berghoher, A.; Bruner, A.; Conner, N.; Dudley, N.; Gidda, S.B.; Kettunen, K.; Mulongoy, K.J.; Pabon-Zamora, L.; Vakrou, A.; Ervin, J.; et al. Recognizing the value of protected areas. In The Economics of Ecosystems and Biodiversity in National and International Policy Making: Ecological and Economic Foundation. Bink, P., Ed.; Earthscan: London, UK, 2011.

55. Gunderson, L. Ecological resilience in theory and application. Annu. Rev. Ecol. Syst. 2000, 31, 425-439. [CrossRef]

56. Machlis, G.E.; Tichnell, D.L. The State of the World's Parks: An International Assessment for Resource Management, Policy and Research; Westview Press: Boulder, CO, USA, 1985; pp. 1-131.

57. Ayivor, J.S.; Gordon, C.; Ntiamoa-Baidu, Y. Protected area management and livelihood conflicts in Ghana: A case study of Digya National Park. Parks 2013, 19, 37-50. [CrossRef]

58. Cooke, E.; Hague, S.; McKay, A. The Ghana Poverty and Inequality Report Using the 6th Living Standards Survey; University of Sussex/Unicef/Ashesie University College: Accra, Ghana, 2016; pp. 1-24. Available online: http://africainequalities.org/wp-content/uploads/2016/07/Ghana_Poverty_and_Inequality_Analysis_ FINAL_Match_20161.pdf (accessed on 27 July 2020).

59. Ayivor, S.J.; Gordon, C.; Ntiamoa-Baidu, Y. Evaluation of management effectiveness of protected areas in the Volta Basin of Ghana: Perspectives on community participation, protected area financing and framework for evaluation. J. Environ. Plan. Policy 2019, 22, 239-255. [CrossRef]

60. Ghana Statistical Service. The Ghana Poverty and Inequality Report Using the 6th Living Standards Survey; University of Sussex/Unicef/Asheshie University College: Accra, Ghana, 2016; pp. 1-43. Available online: https://www.unicef.org/ghana/media/531/file/The\%20Ghana\%20Poverty\%20and\%20Inequality \% 20Report.pdf (accessed on 27 July 2020).

61. World Wide Fund for Nature (WWF). Elephants in the Balance: Conserving Africa's Elephants. 2000. Available online: www.panda.org/resources/publications/species/elephants/index.htmlS (accessed on 1 August 2019).

62. Woodroffe, R.; Thirgood, S.; Rabinowitz, A. People and Wildlife: Conflict or Co-Existence? Cambridge University Press: Cambridge, UK, 2005; pp. 406-477.

63. Ogra, M.; Badola, R. Compensating human-wildlife conflict in protected area communities: Ground-level perspectives from Uttarakhand, India. Hum. Ecol. 2008, 36, 717-729. [CrossRef]

64. Naughton, L.; Rose, R.; Treves, A. The Social Dimensions of Human-Elephant Conflict in Africa: A Literature Review and Case Studies from Uganda and Cameroon; IUCN: Gland, Switzerland, 1999; pp. 1-82. 
65. Cernea, M.M.; Schmidt-Soltau, K. Biodiversity Conservation Versus Population Resettlement: Risks to Nature and Risks to People. In Proceedings of the International CIFOR Conference on Rural Livelihoods, Forests and Biodiversity, Bonn, Germany, 19-23 May 2003; pp. 19-23.

66. Stern, M.J. The power of trust: Toward a theory of local opposition to neighboring protected areas, society \& natural resources. An. Int. J. 2008, 21, 859-875.

(C) 2020 by the authors. Licensee MDPI, Basel, Switzerland. This article is an open access article distributed under the terms and conditions of the Creative Commons Attribution (CC BY) license (http://creativecommons.org/licenses/by/4.0/). 